\title{
Thanks Response Strategies in Cameroon French
}

\author{
Bernard Mulo Farenkia \\ Department of Communication and Languages, Cape Breton University \\ PO Box 5300, Sydney, Nova Scotia, B1P6L2, Canada \\ Tel: 1-902-563-1870. E-mail: bernard_farenkia@cbu.ca
}

Received: September 12, 2018 Accepted: Sep. 27, 2018 Published: October 31, 2018

doi:10.5296/ijl.v10i5.13842ＵRL: https://doi.org/10.5296/ijl.v10i5.13842

\begin{abstract}
This study is designed to investigate strategies used by Cameroon French speakers to respond to gratitude expressions. Principles from three theoretical frameworks, i.e., cross-cultural pragmatics, the conception of French as a pluricentric language and postcolonial pragmatics were used to guide the study. The study was based on data from 148 French-speaking Cameroonian university students using a Data completion task questionnaire. The analysis focused on the pragmatic functions, realization patterns, and situational distribution of thanks response strategies as well as on supportive acts used to modify thanks responses. The results indicate five groups of thanks response strategies emerging from the corpus and the most common strategies used by the respondents are those intended to mitigate or even negate the magnitude of the favor. The findings also show that thanks response strategies are realized in different ways and that they are distributed differently across the three situations retained for this study. It was also found that thanks responses occur either as single acts or as combinations of many acts. The supportive acts attested in the data are employed to mitigate or intensify thanks responses, and to save or enhance the faces of the speaker and/or the addressee. The limitations of the study's findings are highlighted, and avenues for future research outlined.
\end{abstract}

Keywords: thanks responses, politeness, Cameroon French 


\section{Introduction}

In recent years there has been a growing interest in pragmatic and discourse aspects of Cameroon French. This new trend has immensely expanded the scope of scholarly works beyond the traditional phonetical, phonological, morphological, syntactic, lexical, and semantic features of this variety of French. While research in the pragmatics of Cameroon French has so for examined address strategies terms, speech acts such as compliments, responses to compliments, greetings, invitations and condolence expressions, discourse particles, politeness strategies (cf. Mulo Farenkia, 2017), the studies currently available appear not to have given attention to responses to thanks.

In this paper, I will examine thanks responses, in order to highlight linguistic and socio-pragmatic choices made by Cameroon French speakers when they respond to gratitude expressions by their friends, by strangers and by their professors. The research is based on data collected using a Discourse Completion task questionnaire that was administered to a group of French-speaking students in Yaoundé, Cameroon. The study is based on the conception of French as a pluricentric language and on the assumption that

in any language, each illocution can be performed in different ways. The different structural patterns and lexico-semantic devices conventionally available for performing a given illocution [...] represent different strategic option for the speaker. [...] The strategies and forms conventionally employed to realize a given speech act differ across varieties of the same language (Schneider, 2005: 101-102).

This article is structured as follows. Section 2 presents the theoretical background of the study while section 3 gives a brief literature review. Section 4 presents the methodology. The findings are presented and discussed in section 5. Section 6 concludes the study and indicate avenues for future research.

\section{Theoretical Background}

Responses to thanks follow acts of thanking and both speech acts, i.e. thanks and thanks responses, form dialogical units called interactional exchanges or adjacency pairs. Such exchanges

involve two interactants who appear in the local roles of thanker and thankee, with the thanker uttering a thanks and the thankee uttering a response to thanks. [...] A response to thanks is a reactive interactional move which follows a reactive move, as the act of thanking also refers back to an offer or after compliance with a request. [...] Responses to thanks fulfill an important social function. In all cases, a response to an act of thanking terminates the sequence it occurs in, irrespective of the length and complexity of this sequence. Thanks and responses to thanks, thus, form a sequence-final dependent simple exchange (Schneider, 2005: 103).

Thanks responses are discourse strategies used to restore social balance between interlocutors, after a favor has been done. The strategies enacted to this effect may focus on the thanker, the thankee, the debt generated by the favor, the act of thanking itself, etc. For instance, the 
speaker, i.e. the thankee, can downplay the cost of the favor, s/he may express positive feelings towards the hearer, i.e. the thanker, or express pleasure for granting the favor, etc. In order to achieve this, speakers employ a wide range of strategies that could be categorized as politeness, face-saving or face-enhancing strategies. The general point of agreement in cross-cultural pragmatics has been that the realization of speech acts and other pragmatic phenomena vary across languages and cultures. Studies on pluricentrinc languages (cf. Clyne, 1992) have shown that "speakers who share the same native language do not necessarily share the same culture" (Barron and Schneider, 2009: 425) and that "pragmatic differences may occur across varieties of the same language” (Barron and Schneider, 2009: 425). Overall, these studies examine how language specificities and sociocultural norms influence the ways speakers realize speech acts and other pragmatic phenomena. Although this paper is primarily intended to contribute to the growing body of research in Cameroon French pragmatics, the results may also provide an interesting basis for comparative analyses of thanks responses as a pragmatic variable within the cross-cultural and variational pragmatic frameworks.

Pragmatic research on Cameroon French generally takes into account the complex, multilingual, multiethnic and multicultural postcolonial context. For instance, in order to explain linguistic choices made by Cameroonian French speakers when they respond to thanks, it is also necessary to operate on the premises of postcolonial pragmatics. According to Anchimbe and Janney (2011: 421-422), postcolonial pragmatics focuses on "experiences, interactions, challenges, and communicative strategies of members of postcolonial communities using ex-colonial languages, non-colonial languages, pidgin and creoles in their activities". ${ }^{1}$ In other words, the present study considers responses to thanks in Cameroon French (an ex-colonial language in a postcolonial space) as a postcolonial pragmatic variable.

Cameroon's linguistic landscape is very complex. The two official languages, French and English, are used alongside more than 250 indigenous languages and two mixed languages, namely Pidgin English and camfranglais (predominantly spoken among youths in urban areas). Besides, Cameroon is a multiethnic, multicultural and collectivist society. The official languages, French and English, are the sole medium of education while the indigenous languages, Pidgin English and Camfranglais are used in non-official domains. As a result of this heterogeneity, Cameroon French speakers are found to choose complex hybrid linguistic strategies and other patterns of interaction in "which pragmatic practices from different languages, cultures and ethnic groups are subtly combined” (Anchimbe, 2015: 143). Moreover, the multilingual nature of the speech community, different modes of language acquisition, influences of indigenous languages and sociocultural norms and practices, among other factors, have contributed over the years to the emergence of an indigenized variety of French: Cameroon/Cameroonian French. In addition to numerous studies on phonetic, morpho-syntactic and lexical features (cf. Biloa 2003, Mendo Ze 1999, Zang Zang 1998), there is a growing body of research on pragmatic aspects of Cameroonian French. Mulo Farenkia (2017) offers an overview of these studies. Before presenting the methodology of this study it is necessary to briefly look a previous research on responses to thanks.

1 For more details on the scope, aims, and goals of postcolonial pragmatics, see Janney (2009), Anchimbe and Janney (2011). 


\section{Literature review}

Many studies have dealt with gratitude expressions and responses to thanks in languages such as Akan (Agyekum, 2010), German (Marten-Cleef, 1991), English (Aijmer, 1996; Einstein \& Bodman, 1993), Cameroon English (Talla Sando Ouafeu, 2009: 548). In her research on thanks responses in American English, Grando (2016, 11-33) provides an overview of studies on thanking, both in English and in other languages and a review of literature on thanks responses in English and other languages. ${ }^{2}$ Studies from a cross-cultural or contrastive pragmatics perspective compare French and Italian (Held, 1995), German and Spanish (Sosa Mayor, 2006), German and Iraqi Arabic (Ali Mahdi, 2010), French and Romanian (Radulescu \& Scurtu, 2003). Comparative studies that examine regional varieties of English include Jautz's (2008) analysis of gratitude expressions in British and New Zealand English radio programmes and Elwood's (2010) study of gratitude expressions in Irish English and New Zealand English. The few studies on thanks responses include Schneider's (2005) investigation of responses to thanks in three national varieties of English, namely the varieties spoken in Ireland, England and the United States.

As far as French is concerned, the studies currently available mostly analyse responses to thanks alongside other speech acts. For instance, in her book on speech acts in discourse, Kerbrat-Orecchioni (2005) examines apologies, thanks and responses to both acts in the same chapter. She classifies thanks responses (what she calls réactions au remerciement 'reactions to thanks') as either negative or positive, depending on the nature of the exchange (Kerbrat-Orecchioni, 2005: 132-134).

Negative thanks response strategies include expressions that negate the existence of reasons triggering the preceding thanking, (ex. Mais non, c'est Pierre qui a tout préparé! 'But it's Pierre who has prepared everything! (not me)'; expressions employed to minimize the preceding gratitude expression (ex. De rien! 'for nothing', 'it's nothing'); and utterances used to reject the thanker's gratitude expression, while preferring a form of material reciprocation.

Positive strategies include thanks responses that 1) stress the thankee's benevolent willingness to be at the thanker's service: e.g. je vous en prie 'you're welcome'; 2) return the gratitude expression to the thanker: e.g. merci à vous 'thank you as well; 3) minimize the magnitude of the favour: e.g. mais c'est bien normal 'but it's normal', c'est la moindre des choses 'it's a really small thing', ce n'est rien 'it's nothing', y a pas de quoi 'not at all', etc. (cf. Kerbrat-Orecchioni, 2005: 133 -134).

A number of studies have been carried out in the past on gratitude expressions and thanks responses in Cameroonian context. Investigations on the speech act of thanking include Dnzoutchep Nguewo's (2006) comparative study of gratitude expressions in German and some languages spoken in the Western region of Cameroon. The author illustrates the complex structure of the speech act of thanking which he describes as a communicative act made up of several other speech acts, and supported by compliments, good wishes, address terms, etc. Overall, the complexity of gratitude expressions in the Cameroonian languages

\footnotetext{
2 Also see Gesuato (2016).
} 
examined is presented as a reflection of sociocultural norms of many ethnic groups in the Western region of Cameroon. Another investigation of the author yielded similar results (cf. Dnzoutchep Nguewo, 2016). Another analysis of thanking in Cameroonian context is Anchimbe's (2013) study of thanking in written political discourse called 'motions of support”. These are letters read on the radio or TV or published in newspapers, addressed to the president thanking him for a political favour or action deemed beneficial to the group writing the motion. The study shows that thanking in 'motions of support' appears as a communicative act made up of several other speech acts (cf. Anchimbe, 2013, 240). Also interesting is the conclusion that "the sociocultural interactional norms of indigenous Cameroonian cultures could be said to have influenced the structure and content of [Motions of Support] through their decorum and the extensive use of linguistic oratory in traditional hereditary systems” (Anchimbe, 2013: 240-241).

Studies on responses to thanks include Talla Sando's (2009) analysis of examples in Cameroon English. The findings indicate that a large majority of his participants acknowledged thanking by saying 'yes' and that "expressions such as not at all, you are welcome, don't mention it, no problem, great pleasure which appear to be common in many varieties of English did not occur in the Cameroon [...] data.” (Talla Sando, 2009: 547). For the author, the strong preference for responses with 'yes' in Cameroon English "may be a result of an underlyingly Cameroonian thanking routine carried out in English, as thanking is acknowledged in many Cameroonian local languages” (Talla Sando Ouafeu, 2009: 548). Also noteworthy is Mulo Farenkia's (2013) comparative analysis of thanks responses in Canadian English and in Cameroonian English. Based on the taxonomy developed by Aijmer (1996), his analysis showed that the Canadian and Cameroonian respondents employ five different strategies, with the Canadians showing a very strong preference for strategies intended to minimize the favor, while the Cameroonians mostly favor strategies that express appreciation of the addressee. The results yielded seem to indicate different politeness orientations in thanks responses in Canada and Cameroon: while the Canadian English informants mostly prefer negative politeness strategies, Cameroon English respondents most frequently choose positive politeness strategies. There is, to the best of my knowledge, no study on thanks responses in Cameroon French. The present study is an attempt to fill this research gap.

\section{Method}

\subsection{Instrument}

The data for the present study were collected in Yaoundé and Douala, Cameroon. The data were collected by means of a Discourse Completion Task questionnaire (cf. Blum-Kulka et al. 1989) consisting of several situations in which the participants had to realize a range of different speech acts in short dialogues. Each scenario comprised a brief description of the setting, i.e. "the general circumstances [...] and the relevant situational parameters concerning social dominance, social distance and degree of imposition” (Barron, 2008: 43). Three of these situations elicited responses to thanks., the focus of the present study. The three scenarios employed were described as presented in Table 1. 
Table 1. Descriptions of the three situations

\begin{tabular}{|c|c|}
\hline Situation & Description \\
\hline $\begin{array}{l}\text { Situation } 1 \\
\text { [Friend] }\end{array}$ & $\begin{array}{l}\text { Un(e) ami(e) proche vous demande de l'aider à saisir un document à } \\
\text { l'ordinateur. Lorsque le travail est fait, il/elle vous remercie. Vous lui répondez: } \\
\text { 'A close friend asks you to help type a paper. When the work is done, s/he says } \\
\text { "thank you". You respond:' }\end{array}$ \\
\hline $\begin{array}{l}\text { Situation } 2 \\
\text { [Stranger] }\end{array}$ & $\begin{array}{l}\text { Un(e) visiteur/visiteuse s'est égaré(e) sur votre campus. Il/elle vous demande de } \\
\text { le/la conduire à la librairie universitaire. Quand vous y arrivez, il/elle vous dit : } \\
\text { "Merci beaucoup pour votre aide." Vous lui répondez: } \\
\text { 'A stranger got lost on campus. She/he asks you to take him/her to the } \\
\text { university bookstore. When you get there s/he says "thank you very much for } \\
\text { your help". You respond:' }\end{array}$ \\
\hline $\begin{array}{l}\text { Situation } 3 \\
\text { [Professor] }\end{array}$ & $\begin{array}{l}\text { Votre professeur(e) vous demande de l'aider dans l'organisation d'une } \\
\text { conférence. Après cet événement, il/elle vous appelle à son bureau et vous dit : } \\
\text { "Merci beaucoup pour votre aide la semaine dernière ». Vous lui répondez: } \\
\text { 'Your Professor asks you to help him/her organize a conference. After the } \\
\text { event she/he calls you in his/her office and says “thank you very much for your } \\
\text { help last week". You respond:' }\end{array}$ \\
\hline
\end{tabular}

In situations 1 (Friend), the speakers, i.e. the person being thanked for the favour (the thankee), and the addressee, the person thanking for the favour (the thanker), are equal in social status and the relationship is a close one. In situation 2 (Stranger), the interactants do not know each other. The relationship here is one of total social distance. In situation 3 (Professor), the thanker has a higher power position (professor) and the thankee (student) and the thanker (professor) know each other as acquaintances. The respondents were asked to imagine themselves in the three situations and to write down what they would say in order to respond to thanks in each of them.

\subsection{Informants}

A group of 148 French-speaking Cameroonian students participated in the study: 104 students at the University of Douala and 44 students at the University of Yaoundé I. Of the 148 respondents, 100 (67.6\%) were females and 48 (32.4\%) were males. They ranged in age from 18 to 30, however, 105 (70.9\%) of the respondents were between 20 and 25 years old. The respondents were speakers of French in a multilingual context where two official languages (French and English) are permanently in contact with more than 250 native 
languages. All the participants indicated that they acquired French through school education and that they have been speaking French for more than 15 years. With regard to the questions of the main language used at home, 118 (79.7\%) use indigenous languages and 41 (27.7\%) use French. Concerning the main language used with friends: 144 (97.3\%) use French, 11 (7.4\%) use camfranglais, 8 (5.4\%) use English, 3 (2\%) and 3 (2\%) use German. The complex sociolinguistic and cultural background and language choices of the participants certainly also play an important role in the choice of strategies when responding to gratitude expressions in French.

\subsection{Data Analysis}

The participants provided 413 answers for the three questionnaire tasks, namely 142 examples in Situation 1, 133 examples in Situation 2 and 138 examples in Situation 3. The analysis of the data collected involved both quantitative and qualitative aspects. The first step was to segment the examples produced by the participants and to classify each occurrence or token as a strategy belonging one of the following two pragmatic categories: a) head acts or thanks response proper and b) supportive acts. Head acts are the main communicative unit that can realize thanks responses independently of any other unit of a conversational turn. The analysis at this level reveals that responses to thanks appear in the form of single moves/acts, as in De rien 'Not at all/No problem' and in the form of combinations of several moves acts, as in the following examples.

1) De rien monsieur. Tout le plaisir est pour moi. (Stranger $\left.{ }^{3}\right)$

'Not at all /no problem sir. The pleasure is all mine'.

2) C'était un plaisir! N’hésitez-pas de me faire signe si vous avez encore besoin de moi monsieur. (Professor)

'It was a pleasure! Sir, do not hesitate to call me if you need me again'.

3) Il n’y a pas de quoi. Les amis sont faits pour ça. (Friend)

'Don’t mention / Not at all. Friends are meant for that / What are friend for?'

In (1), the respondent combines two head acts to respond to a gratitude expression from stranger. In (2) the utterance c'était un plaisir 'it was a pleasure!' is the head or main act, since it could be employed alone as a thanks response strategy. The other utterance n'hésitez-pas de me faire signe si vous avez encore besoin de moi monsieur. 'Sir, do not hesitate to call me if you need me again' functions as an intensification device for the main act. In (3), il n'y a pas de quoi 'don't mention / not at all' is the main act, i.e. the thanks response proprer, while les amis sont faits pour ça 'friends are meant for that / what are friend for?' is a comment used to further reinforce the minimization of the magnitude of the favour granted.

\footnotetext{
3 Examples from the data are coded as follows: (Friend) means 'response to thanks from a close friend' (Situation 1); (Stranger) means 'response to thanks from a stranger' (Situation 2) and (Professor) means 'response to thanks from a professor' (Situation 3).
} 


\section{Mll Macrothink}

International Journal of Linguistics

ISSN 1948-5425

2018, Vol. 10, No. 5

After identifying the various communicative units employed to realize thanks responses, the next task of the analysis was to classify those units according to their pragmatic functions. The responses were classified in five different groups, based on the coding scheme developed by Aijmer (1996).

The first category, Group A, consists of strategies used to minimize the favor: e.g. Il n'y a pas de quoi 'don't mention it / Not at all'. In other words, these strategies serve to downplay the favor offered to the hearer (thanker) or to indicate that the action taken to grant the favor did not cause any trouble. They represent negative politeness strategies.

The second category, Group B, consists of strategies employed to express pleasure: e.g. C'est un plaisir 'My pleasure'. The thankee make use of such strategies to indicate that s/he had pleasure in granting the favor in question. They represent positive politeness strategies that enhance the positive face of the speaker and the addressee.

The main function of strategies of the third category, Group C, is to express appreciation of the addressee: e.g. Je vous en prie 'You are very welcome'. It is positive politeness strategy.

The fourth category, Group D, consists of strategies used to return thanks, i.e. to thank the addressee (the thanker) in return: e.g. merci aussi 'Thank you too'. They function as positive politeness strategies.

The fifth category, Group E, consists of strategies employed to simply acknowledge thanks: e.g. Ok 'Yeah'. They function as positive politeness strategies (cf. Section 5.1). The examples of the data also show that thanks responses may also consist of combinations of many different strategies, as in De rien monsieur. Tout le plaisir est pour moi. 'Not at all /no problem sir. The pleasure is all mine' [Group A + Group B].

The third step of the analysis consisted in the examination of various realization patterns of the five major thanks response strategies. Using the coding scheme of Schneider (2005), the realization patterns found in the examples were classified into many sub-categories (cf. Sections 5.2 and 5.3). The fourth step of the analysis focused on supportive strategies, i.e. additional acts that come either before or after the head acts and they are employed to either mitigate or aggravate the effect of head acts (cf. Section 5.5), as in Il n'y a pas de quoi. Les amis sont là pour ça. 'Don't mention. Friends are meant for that'. In this example, the supportive act in bold is employed to reinforce the favor minimizing function of the thanks response Il n'y a pas de quoi. The speaker is telling his/her friend that there is no need to thank him/her because the service rendered is a type of help to be expected from a friend. In the next section, the findings of the analysis are presented and discussed.

\section{Results and discussion}

\subsection{Overall distribution}




\section{MInstitute ${ }^{\text {Macrothink }}$}

International Journal of Linguistics ISSN 1948-5425 2018, Vol. 10, No. 5

As already indicated in section 4.3, the thanks responses in the data were classified according to speakers' pragmatic intent regarding the initial gratitude expressions and using Aijmer's (1996) scheme. Table 2 summarizes the distribution of the pragmatic strategies found in the corpus.

Table 2. Distribution of thanks response strategies in the data

\begin{tabular}{|l|l|}
\hline Group and strategy type & Frequency \\
\hline Group A: Minimizing the favor & $348(63 \%)$ \\
\hline Group B: Expressing pleasure & $120(21.7 \%)$ \\
\hline Group C: Expressing appreciation & $44(8 \%)$ \\
\hline Group D: Returning thanks & $35(6.4 \%)$ \\
\hline Group E: Acknowledging the thanks & $5(0.9 \%)$ \\
\hline Total & $\mathbf{5 5 2 ( 1 0 0 \% )}$ \\
\hline
\end{tabular}

Overall, all the strategies documented in Aijmer's (1996) taxonomy are also represented in the Cameroon French data. As displayed in Table 2, the most frequent strategies are those employed to minimize the favor (Group A). They account for $63 \%$ of all thanks responses. Strategies belonging to Group B, i.e. those used to express pleasure, are the second most common strategies in the data: they account for $21.7 \%$ of the corpus. The strategies in the other three groups occur with much lower percentages: strategies in Group C (Expressing appreciation) appear in 44 (8\%) instances, strategies from Group D (Returning thanks) account for 6.4\%., and strategy in Group E (Acknowledging the thanks) represent less than $1 \%$ of the data. In terms of politeness orientation, this result summarized in Table 2 shows that the Cameroonian French speakers mostly prefer negative politeness strategies when they react to gratitude expressions. In other words, they most frequently attempt to save the face of their counterparts by negating or minimizing the magnitude/worth of the favor granted.

The analysis also reveals that the frequencies of the thanks response strategies differ considerably across the three situations (cf. Table 3). 


\section{Macrothink}

Table 3. Distribution of thanks response strategies across the three situations

\begin{tabular}{|l|l|l|l|l|}
\hline & Friend & Stranger & Professor & Total \\
\hline Group A: Minimizing the favor & 128 & 110 & 110 & 348 \\
$(36.8 \%)$ & $(31.6 \%)$ & $(31.6 \%)$ & $(100 \%)$ \\
\hline Group B: Expressing pleasure & 29 & 33 & 58 & 120 \\
Group C: Expressing appreciation & 7 & 14 & 23 & $(100 \%)$ \\
\hline Group D: Returning thanks & $(15.9 \%)$ & $(31.8 \%)$ & $(52.3 \%)$ & $(100 \%)$ \\
\hline Group E: Acknowledging the thanks & 1 & 7 & 19 & 35 \\
\hline Total & $(25.7 \%)$ & $(20 \%)$ & $(54.3 \%)$ & $(100 \%)$ \\
\hline
\end{tabular}

As can be seen in Table 3, the most frequent strategies in the data, i.e. those employed to minimize the favor (Group A), are mostly used when the respondents respond to thanks from their friends (36.8\%). This result is probably due to the close-knit relationship between the interlocutors. Since help appears to be a normal gesture among friends, it would appear impolite not to downplay favors granted to friends. Table 3 also reveals that the second most common strategies in the corpus, those belonging to Group B (expressing pleasure), are most frequent in the Professor situation (48.3\%). The high number of expressions of pleasure in this situation is most possibly due to the vertical relationship between students and professors. By choosing such expressions, the speakers are not only minimizing the favor granted, they are also saying that their gesture was out of respect for the interlocutors and that the speaker considers helping a superior as a very pleasing act. In this respect, such thanks response strategies are face-enhancing acts directed to the superior. The third most common strategies (Group C), i.e. those employed to express appreciation, are mostly preferred in the Professor situation (53.2\%). Strategies belonging to Group D (returning thanks) are most frequent in the Professor situation (54.3\%). The least employed strategies in the data, namely strategies belonging to Group E (acknowledging the thanks), occur four times in the Stranger situation, once in the Friend situation, but there is no token of this strategy type in the Professor 


\section{Al Macrothink}

International Journal of Linguistics ISSN 1948-5425 2018, Vol. 10, No. 5

situation. Let us now turn to the realization patterns of thanks response strategies found in the data.

\subsection{Realization types of thanks response strategies}

With respect to the realization types of the response strategies presented in the previous section, it was found that the respondents make many different choices. The realization patterns identified were classified following a modified version of Schneider's (2005) typology. In his inventory of linguistic realization forms of thanks in English, Schneider identified eight realization types, namely No Problem; Welcome; Pleasure; Anytime; Thanks; Don't Worry About It; Yeah; Don't Mention It. (cf. Schneider 2005: 116). Based on this typology, I identified and classified realization types of thanks response strategies in the Cameroonian French corpus. Table 4 summarizes the frequencies and distribution of the patterns found.

Table 4. Distribution of realization patterns

\begin{tabular}{|l|l|}
\hline Realization type & Frequency \\
\hline PAS DE QUOI & $155(28.1 \%)$ \\
\hline DE RIEN & $152(27.5 \%)$ \\
\hline PLAISIR & $96(17.4 \%)$ \\
\hline NORMAL & $41(7.5 \%)$ \\
\hline JE T'EN PRIE/VOUS EN PRIE & $36(6.5 \%)$ \\
\hline MERCI & $35(6.4 \%)$ \\
\hline HONNEUR/JOIE/SATISFACTION & $24(4.3 \%)$ \\
\hline A VOTRE SERVICE & $8(1.4 \%)$ \\
\hline D'ACCORD & $5(0.9 \%)$ \\
\hline TOTAL & $\mathbf{5 5 2 ( 1 0 0 \% )}$ \\
\hline
\end{tabular}

Overall, nine realization types were employed by the respondents. They are De Rien; Pas De Quoi; Normal; Plaisir ; Je T'en/Vous En Prie; Merci ; Honneur/Joie; A Votre Service, and D'accord. These realization types were identified based on the content they convey, without considering their linguistic realization forms. As can be seen in Table 4, the three most 
favored realization types in the data are, in decreasing order, Pas de quoi 'not at all', which accounts for $28.1 \%$ of the data, De rien "for nothing", which accounts for $27.5 \%$ of all examples, and Plaisir "Pleasure", which accounts for $17.4 \%$ of all occurrences. Overall, the three most frequent types represent more than $70 \%$ of all tokens in the data. The next three realization types account each for less than $10 \%$ and more than $5 \%$ of all realization types: these are Normal (7.5\%), Je t'en prie/vous en prie (6.5\%) and Merci (6.4\%). The remaining three realization types occur with much lower percentages: Honneur/Joie (4.3\%), À Votre Service (1.4\%) and D'accord (0.9\%). The realization types identified were also examined in terms of the pragmatic strategies they relate to. Table 5 presents the results of the analysis.

Table 5. Distribution of realization types of thanks response strategies

\begin{tabular}{|l|l|l|}
\hline \multicolumn{2}{|l|}{ Pragmatic strategy and realization type } & Frequency \\
\hline \multirow{2}{*}{ Group A } & PAS DE QUOI & $155(28.1 \%)$ \\
\cline { 2 - 3 } & DE RIEN & $152(27.5 \%)$ \\
\cline { 2 - 3 } & NORMAL & $41(7.5 \%)$ \\
\hline \multirow{2}{*}{ Group B } & PLAISIR & $96(17.4 \%)$ \\
\cline { 2 - 3 } & HONNEUR/JOIE & $24(4.3 \%)$ \\
\hline \multirow{2}{*}{ Group C } & JE T'EN/VOUS EN PRIE & $36(6.5 \%)$ \\
\cline { 2 - 3 } & À VOTRE SERVICE & $8(1.4 \%)$ \\
\hline Group D & MERCI & $35(6.4 \%)$ \\
\hline Group E & D'ACCORD & $5(0.9 \%)$ \\
\hline Total & & $\mathbf{5 5 2 ( 1 0 0 \% )}$ \\
\hline
\end{tabular}

First, Table 5 shows that thanks response strategies in Group A occur using three different realization types, namely Pas de quoi 'not at all', De rien 'for nothing' and Normal 'it's normal'. Strategies belonging to Group B have two realization types, Plaisir 'pleasure' and Honneur 'honor'/Joie 'joy'. Strategies from Group C may occur in the form of Je t'en prie 'Welcome' and in the form of À votre service 'at your service'. The strategies of the two other groups have only once realization type each, namely Merci 'thanks' (Group D) and D'accord 'Okay" (Group E). The situational distribution of the realization types in the data reveals very interesting choices by the respondents, as can be seen in Table 6 . 
Table 6. Distribution of the realization patterns across the three situations

\begin{tabular}{|c|c|c|c|c|c|}
\hline \multicolumn{2}{|c|}{ Strategy and realization type } & \multirow{2}{*}{$\begin{array}{l}\text { Friend } \\
63 \\
(41.5 \%)\end{array}$} & \multirow{2}{*}{$\begin{array}{l}\text { Stranger } \\
44 \\
(28.9 \%)\end{array}$} & \multirow{2}{*}{$\begin{array}{l}\text { Professor } \\
45 \\
(29.6 \%)\end{array}$} & \multirow{2}{*}{$\begin{array}{l}\text { Total } \\
152 \\
(100 \%)\end{array}$} \\
\hline Group A & DE RIEN & & & & \\
\hline & PAS DE QUOI & $\begin{array}{l}52 \\
(33.5 \%)\end{array}$ & $\begin{array}{l}50 \\
(32.3 \%)\end{array}$ & $\begin{array}{l}53 \\
(34.2 \%)\end{array}$ & $\begin{array}{l}155 \\
(100 \%)\end{array}$ \\
\hline & NORMAL & $\begin{array}{l}13 \\
(31.7 \%)\end{array}$ & $\begin{array}{l}16 \\
(39 \%)\end{array}$ & $\begin{array}{l}12 \\
(29.3 \%)\end{array}$ & $\begin{array}{l}41 \\
(100 \%)\end{array}$ \\
\hline \multirow[t]{2}{*}{ Group B } & PLAISIR & $\begin{array}{l}19 \\
(19.8 \%)\end{array}$ & $\begin{array}{l}26 \\
(27.1 \%)\end{array}$ & $\begin{array}{l}51 \\
(53.1 \%)\end{array}$ & $\begin{array}{l}96 \\
(100 \%)\end{array}$ \\
\hline & HONNEUR/JOIE & $\begin{array}{l}10 \\
(41.6 \%)\end{array}$ & $\begin{array}{l}7 \\
(29.2 \%)\end{array}$ & $\begin{array}{l}7 \\
(29.2 \%)\end{array}$ & $\begin{array}{l}24 \\
(100 \%)\end{array}$ \\
\hline \multirow[t]{2}{*}{ Group C } & $\begin{array}{l}\text { JE T'EN/VOUS } \\
\text { EN PRIE }\end{array}$ & $\begin{array}{l}4 \\
(12.1 \%)\end{array}$ & $\begin{array}{l}11 \\
(33.3 \%)\end{array}$ & $\begin{array}{l}18 \\
(54.5 \%)\end{array}$ & $\begin{array}{l}33 \\
(100 \%)\end{array}$ \\
\hline & $\begin{array}{l}\text { A VOTRE } \\
\text { SERVICE }\end{array}$ & $\begin{array}{l}3 \\
(27.3 \%)\end{array}$ & $\begin{array}{l}3 \\
(27.3 \%)\end{array}$ & $\begin{array}{l}5 \\
(45.4 \%)\end{array}$ & $\begin{array}{l}11 \\
(100 \%)\end{array}$ \\
\hline Group D & MERCI & $\begin{array}{l}9 \\
(25.7 \%)\end{array}$ & $\begin{array}{l}7 \\
(20 \%)\end{array}$ & $\begin{array}{l}19 \\
(54.3 \%)\end{array}$ & $\begin{array}{l}35 \\
(100 \%)\end{array}$ \\
\hline Group E & D’ACCORD & $\begin{array}{l}1 \\
(20 \%)\end{array}$ & $\begin{array}{l}4 \\
(80 \%)\end{array}$ & 0 & $\begin{array}{l}5 \\
(100 \%)\end{array}$ \\
\hline
\end{tabular}

As displayed in Table 6, De rien is mostly used by the respondents in the Friend situation (41.5\%), while this realization type is almost equally distributed in the Stranger situation (28.9\%) and in the Professor situation (29.6). By contrast, Pas de quoi, the most frequent realization type in the data, appears to be equally distributed in the three situations. Plaisir, the third most preferred realization type, appears mostly in the Professor situation. The respondents mostly employ the realization type Normal in the Stranger situation (39\%). Table 
4 also indicates that Merci and Je t'en/vous en prie, the firth and sixth realization types, are most common in the Professor situation. The least employed realization pattern D'accord mostly appears in the Stranger situation and is not employed in the Professor situation. Let's now turn to the linguistic realization forms of the various realization patterns presented in Table 3.

\subsection{Linguistic realization of thanks response strategies}

Overall, the strategies employed to minimize the benefit occur in three different realization types. Pas de quoi 'not at all', the most frequent realization type, is generally realized using the elliptical structures pas de quoi and y'a pas de quoi. Also attested are syntactically more elaborate structures such as il n'y a (vraiment) pas de quoi (me dire merci) 'there is (really) nothing (to thank me for)'. Other realization forms of this pattern include expressions such as Ne vous inquiétez pas; Ne vous en faites pas 'Don't worry'; Ça ne vaut pas la peine de me remercier 'it is not worth the effort to thank me'; Vous n'avez pas à me remercier 'you don't have to thank me'. De rien "for nothing”, the second most common type is realized as De rien 'for nothing'; C'est rien 'it's nothing'; Sans souci(s) 'no problem/worries/troubles'; Il n'y a pas de souci(s) 'there is no problem/worry'. These forms may also be accompanied by address terms (e.g. mais c'est rien monsieur 'but it's nothing sir'). Normal is realized using expressions like c'est normal/naturel; cela va de soi 'it is normal/natural'; c'est la moindre des choses 'it's really a small thing'. In some cases, intensive adverbials like tout 'very', tout à fait 'absolutely' and clauses are added, as in c'est (tout/tout à fait) normal/natural (que je t'aide) 'it's (very/absolutely) normal/natural (that I help you out)'.

The thanks response strategies used to express the speaker's pleasure for providing the benefit (Group B) occur in the Plaisir and in the Honneur/Joie realization types. The first type, Plaisir "Pleasure", is by far the most preferred realization type in Group B (96 tokens of $120 ; 80 \%)$. It is realized using expressions like c'est un plaisir 'it's a pleasure', ce fût un plaisir 'it was a pleasure'; le plaisir est partagé 'the pleasure is mutual'; Tout le plaisir a été pour moi 'the pleasure was all mine'. Adverbs or adjectives may be used to reinforce these expressions, as in c'était un réel/grand plaisir 'it as a great pleasure'. These utterances are introduced by c'est/c'était/ce fut un "it is/was a" and followed additional clauses, as in ce fut un réel plaisir (pour moi de vous aider) 'It was a real pleasure to help you'. The second realization type in Group B, Honneur/Joie, is employed to express the speaker's feeling of honor, joy or satisfaction for helping the interlocutor. The utterances employed to this effect are expressions like c'est un honneur de t'aider 'It's an honor to help you'; j'en suis fier 'I am proud about it'. Joy is expressed as follows: Je suis ravi de vous rendre ce service 'I am happy to render this service'; Je suis heureuse de t'avoir été utile 'I am happy to have been useful to you'. Satisfaction is expressed as Je suis satisfait de t'avoir aidé 'I am satisfied to have helped you'.

The strategies used to express appreciation of the addressee (the thanker) (Group C), appear using two realization types. The first type, Je t'en/vous en prie 'Welcome", is realized as je t'en prie/je vous en prie 'you are welcome'. The second type, À votre service, is realized as je 
suis à votre (entière) disposition 'I am (entirely) at your service'; C'est quand vous voulez 'anytime'.

Merci is the only realization type for strategies employed to reciprocate the thanks (Group D). It is realized as merci 'thanks'. This elliptical form can be accompanied by and adverbs like aussi “too' as in merci aussi 'Thank you too'. Another expression attested is c'est moi qui vous remercie 'It's me too thank you'.

Finally, the strategies employed to acknowledge the thanks appear in only one realization type, namely D'accord, realized as d'accord 'okay'; Tant mieux 'good'; Ok; Okay; Oui 'yes'.

In the sections above, it is shown that some respondents use lexical and syntactic modifiers (internal modifiers) to either mitigate or upgrade the impact of their thanks responses. Speakers also use external modifiers to support their thanks responses.

\subsection{Supportive Strategies}

Several speech acts are used as support acts in the data. Of the 144 tokens of supportive acts attested 63 (43.8\%) occur in the Friend situation, 54 (37.5\%) tokens appear in the Stranger situation, while 27 (18.7\%) instances are used in the Professor situation. With respect to their contents and pragmatic functions, the 144 supportive acts were classified in different groups.

\subsubsection{Focusing on Friendship}

The first group consists of supportive acts that occur exclusively in the friend situation. Their pragmatic function is to highlight the existing friendship between speaker (thankee) and hearer (thanker) as (one of) the motive(s) for providing the benefit. The speaker attempts to minimize the favor and to flatter the face of the addressee by reminding the interlocutor of their close relationship. In the examples collected, the cordial relationship is expressed either directly as in De rien. C'est entre nous camardes. ${ }^{4}$ 'Not at all. It's between friends' or indirectly, as in Pas de quoi. Ton travail est aussi le mien. 'Don't mention it. Your work is also mine'. In some examples, the supportive acts are employed to exhort speaker and addressee to help each other or to cooperate beyond the present situation. In this case, the speaker explicitly says that friends are meant to help or to be helped, as in Il n'y a pas de quoi. Les amis sont faits pour ça. 'Don't mention it. Friend are meant for that'. Overall, the expression of social responsibility to friends and the strengthening of cordial relationships are the motivations behind such supportive acts.

\subsubsection{Focusing on Speaker's Profits from the Help Rendered}

The second group consists of supportive acts that serve to indicate that the speaker also benefited from favor. Acts belonging to this category appear in the formal situation (professor), as in (4) and in the informal situation (friend), as in (5). In (4), the speaker expresses appreciation of their professor and their pleasure in helping the interlocutor in organizing the conference. The supportive act relates to the success of the conference and it further highlights the fact the speaker also gained something from it. In (5), the speaker

\footnotetext{
4 The supportive acts are in bold.
} 
minimizes the favor and goes ahead to indicate the work allowed them to further develop their computer skills. In this case, the supportive act could be interpreted as a thanks reciprocation strategy.

4) Je vous en prie. Ce fût un plaisir. J'en ai beaucoup appris. (Professor)

'You are welcome. It was a pleasure. I learned a lot from it (the conference)'.

5) De rien. Cela m’a permis aussi d'améliorer mes performances. (Friend)

'Don't mention it. It also helped me to further develop my skills.'

\subsubsection{Focusing on the Conviction that the Other Would have Done the Same}

The supportive acts belonging to this category are employed to enhance the positive face of the interlocutor by expressing the speaker's conviction that the addressee would have acted in the same way. They generally occur after the thanks response proper as in (6). In this example the speaker explicitly minimizes the thanks and then indicates that $\mathrm{s} / \mathrm{he}$ thinks the addressee would have rendered the same, thus presenting him/her as a helpful person. First, the positive image functions as leverage to provide the benefit for which the speaker is being thanked. Secondly, it is used to further maximize the minimizing connotation of the first utterance. The speaker is actually saying: “you don't have to thank me because you would have done the same thing for me". The face-enhancing supportive act serves as a justification of the reason why the speaker is minimizing the favor.

6) C'est rien. Je pense quand même que tu aurais fait pareil pour moi. (Friend)

'It's nothing. I still think you would have done the same thing for me.'

\subsubsection{Focusing on Speaker's Willingness/Duty to Help}

The supportive acts in this category are intended to stress the speaker's willingness or duty to help, as in (7), where the speaker minimizes the favor, indicates that friendship is the motive behind the help and goes on to invoke their commitment to help the interlocutor anytime. Other supportive acts describe "the benefit as ordinary rather than special or costly" (Grando, 2016: 62), as in (8). The supportive act in (8) could be considered as a reiteration of the head act ce n'était pas grand chose 'it was not a big deal'.

7) De rien ma puce ! C'est l'amitié. Je suis là pour toi ma belle et tu pourras toujours compter sur moi. (Friend)

'Not at all darling. It is friendship. I am there for you beautiful and you can always rely on me'.

8) Ce n'était pas grandiose. Ce n'était qu'une aide. (Stranger)

'It was not a big deal. It was just a help.'

5.5.5 Closing the Exchange on a Very Positive Tone 


\section{Macrothink Institute $^{T M}$}

The supportive acts in this category appear in the form of farewell and wish to meet the interlocutor in the future, as in (9). In (9), the speaker minimizes the thanks then wishes the addressee a nice stay on the campus and expresses the hope to meet him/her next time.

9) Vous n'avez pas à me remercier, passez tout simplement un bon séjour et à nous revoir prochainement s'il plait à Dieu. (Stranger)

'You don’t have to thank me. I just want to wish you a nice stay and see you next time by the grace of God.'

\subsubsection{Promise to Help Anytime and Expression Reciprocity}

Many different supportive acts belong to this group. The first type is the act of promising. It serves to express the commitment help the addressee anytime whenever assistance is needed, as in (10). The supportive acts of the second sub-group are those intended to assert reciprocity with the interlocutor. These include welcoming as in (11), expressions of empathy, as in (12), wishes, as in (13).

10) Il n’y a pas de quoi. Je serai toujours disponible quand besoin sera. (Friend)

'Don’t mention it. I will always be available when needed.'

11) Je vous en prie. Vous êtes la bienvenue dans notre campus. (Stranger)

'You are welcome. Welcome to our campus.'

12) Il n'y a pas de quoi me remercier, car tout le monde peut s'égarer et avoir besoin d'aide. (Stranger)

'You don’t have to thank me because anybody can get lost and need help.'

13) Il n'y a pas de quoi! Faites un bon choix du livre que vous voulez acheter et passez une bonne journée. (Stranger)

'Don't mention it. I wish you a good choice of the book you want to buy and have a nice day'.

The last group consists of a variety of supportive acts. They include advice, offering help, requests, etc. The act of advising serves to encourage the addressee to do something with respect to the favor granted. In (14), the speaker explicitly tells the addressee that if they do what they are advised to do, they should be able to help each other and other people as well in the future. It is important to note in this example that the expression quand tu as le temps 'when you have time' and the two justifications serve as mitigations for the advice.

14) De rien, mais il faut aussi apprendre à saisir quand tu as le temps car cela peut aussi aider quelqu'un comme toi demain et t'aider aussi dans d'autres situations. (Friend).

'Not at all, but you also have to learn how to type when you have time because it could also help somebody like you in the future and help you out in other situations'. 
Another type of advice is illustrated in (15): the addressee is encouraged to be more careful in order not to miss their way. The advice is mitigated by a justification.

15) De rien Monsieur, ne vous en faites pas, prochainement il faut prêter attention. Ce campus est vraiment quelque chose à s'égarer, mais il n'est même pas grand. (Stranger)

'Not at all sir, don't worry about it, you have to be more careful next time. You can easily go astray on this campus, but it's not that big'.

After responding to the gratitude expression, the speaker may use the act of offering help to indicate their readiness to help (again) in the future. This consolidates the student-professor relationships, as in (16) and solidifies social bonds, as in (17).

16) C'était un plaisir ! N'hésitez-pas de me faire signe si vous avez encore besoin de moi monsieur. (Professor)

'It was my pleasure. Sir, don’t hesitate to contact me if you need me again.'

17) De rien, le plaisir est partagé. Tu peux revenir quand tu le souhaites. (Friend)

'No problem/not at all, the pleasure is also mine. You can come back when you want to'.

The speaker can make a request for reciprocation in the future, as in (18) or for a different kind of reward (money, drink, etc.), as in (19).

18) Merci aussi, mais j'espère que tu m'aideras de même lorsque j'aurai besoin de faire saisir mon devoir si je n'ai pas le temps. (Friend)

'Thank you too, but I hope you will help me when I need to type my homework and I don't have time'.

19) De rien. Mais monsieur il n'y a pas un pot pour moi? (Professor)

'No problem. But sir is there a drink for me?'

\subsection{Complexity of Thanks Response Utterances}

The examples from the corpus show that the respondents use simple structures, i.e. those consisting of only one move or utterance as in Y'a pas de quoi 'not at all', and complex structures, i.e. those consisting multiple moves, to respond to thanks. Table 7 summarizes the distribution of simple and complex thanks responses in the data.

Table 7. Distribution of simple and complex thanks responses 


\begin{tabular}{|l|l|l|l|l|l|}
\hline Types of thanks response & Friend & Professor & Stranger & Total \\
\hline Simple thank responses & 62 & 68 & 57 & $187(45.3 \%)$ \\
\hline $\begin{array}{l}\text { Complex } \\
\text { thanks } \\
\text { responses }\end{array}$ & $\begin{array}{l}\text { Two-move } \\
\text { responses }\end{array}$ & 54 & 46 & 61 & $161(39 \%)$ \\
\cline { 2 - 7 } & $\begin{array}{l}\text { Three-move } \\
\text { responses }\end{array}$ & 15 & 15 & 16 & $46(11.1 \%)$ \\
\cline { 2 - 7 } & $\begin{array}{l}\text { More } \\
\text { three-move } \\
\text { responses }\end{array}$ & 11 & 4 & 4 & $19(4.6 \%)$ \\
\hline Total & \multicolumn{142}{|l|}{} & $\mathbf{1 3 3}$ & $\mathbf{1 3 8}$ & $\mathbf{4 1 3}(\mathbf{1 0 0} \%)$ \\
\hline
\end{tabular}

Overall, the Cameroon French speakers use more complex thanks responses (54.7\%) that the simple ones (45.3\%). Of the 413 tokens attested in the data, there are 226 instances of complex thanks responses and 187 tokens of simple thanks responses. The analysis of the number of moves used to construct complex thanks responses reveals that two-move responses, as in (20), are by far the most frequently employed: 161 examples of two-move responses (39\% of the data) were found. Three-move responses, as in (21), appear with a much lower percentage (11.1\%). Thanks responses consisting of more than three-moves, as in (22), are the least employed in the data: only 19 tokens were found, representing $4.6 \%$ of the data.

20) De rien monsieur. Tout le plaisir était pour moi de vous apporter mon aide. (Professor)

'No problem sir. It was my pleasure to help you.'

21) Je vous en prie monsieur, tout le plaisir est le mien. C'est moi qui vous remercie de m'avoir accordé cet honneur. (Professor)

'You are welcome sir. The pleasure is all mine. I am the one to thank you for the honor.'

22) Non gars! C'est rien. Tu es mon pote pourquoi ? Il fallait bien que je te help car un jour je peux aussi être dans le dem tu me help aussi. (Friend)

'No buddy. No problem. What are friends for? I had to help because I may one day be in need and you would also help.' 


\section{Macrothink}

International Journal of Linguistics

ISSN 1948-5425

2018, Vol. 10, No. 5

Table 7 also shows that simple responses mostly appear in the professor situation, while complex responses are equally distributed in the Friend situation and the Stranger situation. A breakdown of the various complex responses shows that two-move responses are by far the most preferred strategy across the three situations, albeit with different frequencies (Stranger 61/161 (37.9\%), Friend 54/161 (33.5\%); Professor 46/161 (28.6\%)). Table 7 also indicates that three-move responses are equally distributed across the three situations, whereas responses with more than three moves are most frequently employed in the Friend situation $(11 / 19,57.9 \%)$

\section{Conclusion}

The goal of this study was to describe thanks response strategies in Cameroon French. The analysis illustrated a wide range of strategies employed by the informants to respond to gratitude expressions in three different situations. Five groups of strategies emerge from the examples collected and the most common thanks response strategies are those employed to mitigate and/or negate the magnitude of the favor (Group A). Such strategies account for $63 \%$ of the data and they appear in three different realization patterns, namely Pas de quoi, De rien, and Normal. The other thanks response strategies occur with much lower frequencies. Strategies used to express pleasure for providing the benefit account for $21.7 \%$, those employed to express appreciation of the addressee represent $8 \%$, strategies used to return the thanks account for $6.8 \%$, and strategies employed to acknowledge the thanks represent only $0.9 \%$ of the data. The findings also showed that the thanks response strategies identified in the corpus take different realization patterns and are distributed differently in the three situations retained for this study. It was also found that thanks responses occur either as single acts or as combinations of several acts (double or head acts or head acts and supportive acts). The various supportive acts attested, as the analysis above has shown, serve to mitigate and intensify the preceding or following head acts, and to save or enhance the faces of the speaker and/or the addressee.

The present study has some limitations. First, it is based on written questionnaire data. It is likely that the thanks response strategies illustrated in this current work do not represent Cameroon French speakers' choices in natural occurring situations. However, the results obtained here still reflect potential trends of Cameroon French speakers' behaviour in thanks thanks response exchanges. Second, the study examined examples from just three situations. It is difficult to claim that the results obtained can be generalized to all situations. Third, the study did not consider other factors affecting the use of thanks response strategies, such as age, socio-economic groups, gender, ethnic group, etc. It is likely that such factors may lead to the use of strategies that differ from those found in the present study. Future studies can expand the scope of the current study by overcoming these limitations.

\section{Acknowledgement}

Funding for this project was provided by the Office of Research and Graduate Studies of Cape Breton University (Canada). The author is indebted to all the contacts and participants in the study. 


\section{Ml Macrothink}

International Journal of Linguistics

ISSN 1948-5425

2018, Vol. 10, No. 5

\section{References}

Agyekum, K. (2010). The Sociolinguistics of Thanking in Akan. Nordic Journal of African Studies, 19(2), 77-97.

Aijmer, K. (1996). Conversational Routines in English. Convention and Creativity. London \& New York: Longman.

Ali Mahdi, H. (2010). Die Routineformeln im Deutschen und im Irakisch-Arabischen Eine empirische Untersuchung. Ph.D. Thesis, Philipps-University. Marburg.

Anchimbe, E. (2013). 'Motions of support' and the communicative act of thanking in political discourse. In: Fetzer, A. (ed.), The Pragmatics of Political Discourse. Explorations across Cultures. Amsterdam: John Benjamins: pp. 219-242

Anchimbe, E., \& Janney, R. (2011). Postcolonial pragmatics: An introduction. Journal of Pragmatics, 43(6), 1451-1459.

Barron, A. (2008). The structure of requests in Irish English and English. In: Schneider K. P \& Barron A. (eds.), Variational Pragmatics. A Focus on Regional Varieties in Pluricentric Languages. Amsterdam/Philadelphia: John Benjamins, pp. 35-67.

Barron, A., \& Schneider, K. P. (2009). Variational pragmatics: Studying the impact of social factors on language use in interaction. Intercultural Pragmatics, 6(4), 425-442.

Biloa, E. (2003). La langue française au Cameroun. Bern: Peter Lang.

Brown, P., \& Levinson, S. (1987). Politeness: Some universals in language usage. Cambridge: Cambridge University Press.

Clyne, M. (ed.) (1992). Pluricentric languages. Different norms in different nations. Berlin /New York: Mouton de Gruyter.

Dnzoutchep, N. B. D. (2006). Dankbarkeitsbekundung in Deutschland und Kamerun als kommunikatives und soziokulturelles Phänomen, Frankfurt am Main: Peter Lang.

Dnzoutchep, N. B. D. (2016). De la complexité du remerciement en milieu Bamiléké (Ouest - Cameroun). In : Mulo Farenkia, B. (ed.), Im/politesse et rituels interactionnels en contextes plurilingues et multiculturels. Situations, Stratégies, Enjeux. Frankfurt am Main: Peter Lang, pp. 295-310

Eisenstein, M., \& Bodman, J. (1993). Expressing gratitude in American English”. In: Kasper G. \& Blum-Kulka S. (eds.), Interlanguage Pragmatics. Oxford: Oxford University Press, pp. 64-81.

Elwood, K. (2010). An analysis of expressions of gratitude in Irish English and New Zealand English. The Cultural Review, 36, 109-153.

Gesuato, S. (2016). Reponding to gratitude in elicited oral interaction. A Taxonomy of communicative options. Lingue e Linguaggi, 19, 197-220. 


\section{Macrothink}

International Journal of Linguistics

ISSN 1948-5425

2018, Vol. 10, No. 5

Grando, A. (2016). Acknowledging gratitude in American English: a pragmatic study of native speakers' role-play data. MA Thesis. Università degli Studi di Padova. Retrieved from http://tesi.cab.unipd.it/52395/1/ANGELA_GRANDO_2016.pdf

Held, G. (1995). Verbale Höflichkeit. Studien zur linguistischen Theorienbildung und empirische Untersuchung zum Sprachverhalten französischer und italienischer Jugendlicher in Bitt- und Danksituationen. Narr.: Tübingen.

Janney, R. (2009). Pragmatics in postcolonial contexts: For Paul Mbangwana. Annals of the Faculty of Arts and Social Sciences, University of Yaoundé I (Special edition in Honour of Professor Paul N. Mbangwana), pp. 101-108.

Janney, R. W. (2006). Postcolonial pragmatics. Plenary paper presented at the International Conference on Pragmatics, Pune, India, 15 -17 December 2006.

Jautz, S. (2008). Gratitude in British and New Zealand radio programmes. Nothing but gushing? In: Schneider K. P. \& Barron A. (eds.), Variational Pragmatics. A Focus on Regional Varieties in Pluricentric Languages. Amsterdam/Philadelphia: John Benjamins, pp. 141-178.

Kerbrat-Orecchioni, C. (2005). Les actes de langage dans le discours. Paris: Armand Colin.

Marten-Cleef, S. (1991). Gefühle ausdrücken. Die expressiven Sprechakte. Göppingen: Kümmerle Verlag.

Mayor, I. S. (2006). Routineformeln im Spanischen und im Deutschen. Eine pragmalinguistische kontrastive Analyse. Wien: Praesens Verlag.

Mendo, Z. G. (1999). Le français, langue africaine : enjeux et atouts pour la francophonie; éléments de stratégies. Paris : PubliSud.

Mulo, F., \& Bernard (2013). 'All thanks goes to the Almighty': A Variational and postcolonial pragmatic perspective on responses to thanks. Sino-US English Teaching, 10(9), 707-724.

Radulescu, A., \& Scurtu, G. (2003). Expression de la relation interpersonnelle de politesse: Divergences de structuration et d'emploi en français et roumain. Information Grammaticale, 99, 11-12.

Schneider, K. P. (2005). 'No problem, you're welcome, anytime': Responding to thanks in Ireland, England and the USA. In: Barron A. \& Schneider, K. P. (eds.), The Pragmatics of Irish English. Berlin \& New York: Mouton, pp. 101-139.

Talla, S., \& Ouafeu, Y. (2009). Thanking responders in Cameroon English. World Englishes, 28(4), 544-551.

Wierzbicka, Anna. (2003). Cross-Cultural Pragmatics: The Semantics of Human Interaction. Berlin \& New York: Mouton de Gruyter.

Zang Zang, P. (1998). Le français en Afrique. Munich : Lincom Europa. 


\section{Copyrights}

Copyright for this article is retained by the author(s), with first publication rights granted to the journal.

This is an open-access article distributed under the terms and conditions of the Creative Commons Attribution license (http://creativecommons.org/licenses/by/4.0/) 